\title{
Rimonabant: the evidence for its use in the treatment of obesity and the metabolic syndrome
}

\author{
Mark Waterlow, Paul Chrisp \\ Core Medical Publishing, Knutsford, UK
}

\begin{abstract}
Introduction: Obesity and overweight affect over 1 billion people worldwide and are leading causes of morbidity and mortality. Clinical features of obesity converge with those of the metabolic syndrome and type 2 diabetes, greatly increasing the risk of long-term adverse outcomes.
\end{abstract}

Aims: To review the evidence on rimonabant, a novel CB1 receptor antagonist, for the treatment of obese and overweight patients.

Evidence review: There is clear evidence that rimonabant $20 \mathrm{mg} /$ day in conjunction with a hypocaloric diet causes a mean weight loss of $4.6 \mathrm{~kg}$ in obese and overweight patients after 1 year's treatment, with approximately $50 \%$ of patients achieving a weight loss of $\geq 5 \%$. One study demonstrated that weight loss is maintained for up to 2 years. The drug also improves lipid and glycemic cardiovascular risk factors, including high-density lipoprotein cholesterol and insulin resistance, and reduces waist circumference, thus reducing the prevalence of metabolic syndrome. Treatment of obese and overweight diabetic patients with rimonabant decreases glycosylated hemoglobin $\left(\mathrm{HbA}_{1 \mathrm{c}}\right)$, including patients previously untreated for diabetes. The effect of rimonabant appears to be partly independent of weight loss.

Rimonabant $20 \mathrm{mg} /$ day is generally well tolerated, with mild to moderate transient adverse effects including nausea, diarrhea, dizziness, and anxiety. Approximately $14 \%$ of patients receiving rimonabant $20 \mathrm{mg} /$ day discontinued due to adverse effects, primarily depressed mood, although overall rates of depression did not differ significantly compared with placebo.

Place in therapy: The evidence supports the use of rimonabant $20 \mathrm{mg} /$ day along with dietary modification to reduce cardiovascular risk factors in obese and overweight patients, including those with diabetes. The drug is contraindicated in patients receiving antidepressants. Long-term data on cardiovascular outcomes, morbidity, and mortality are eagerly awaited.

Core Evidence. 2007;2(3):173-187.

Key words: metabolic syndrome, obesity, rimonabant, type 2 diabetes

Core evidence place in therapy summary for rimonabant 20 mg/day in obese and overweight patients in combination with hypocaloric diet

\begin{tabular}{|c|c|c|}
\hline Outcome measure & Evidence & Implications \\
\hline \multicolumn{3}{|l|}{ Patient-oriented evidence } \\
\hline Quality of life & Moderate & Rimonabant may improve quality of life, particularly physical functioning \\
\hline Reduced morbidity and mortality & No evidence & Should be benefit but requires confirmation \\
\hline Tolerability & Clear & $\begin{array}{l}\text { Depressed mood may cause discontinuation of treatment in some patients, } \\
\text { and rimonabant should not be used in those with depression. Rimonabant } \\
\text { can cause mild and transient adverse effects, particularly nausea, diarrhea, } \\
\text { dizziness, and anxiety }\end{array}$ \\
\hline \multicolumn{3}{|l|}{ Disease-oriented evidence } \\
\hline Weight reduction in medium term ( $<1$ year) & Clear & Weight loss $\geq 5 \%$ can be achieved in approximately $50 \%$ of patients \\
\hline Weight reduction in long term (>1 year) & Moderate & Weight loss can be maintained for up to 2 years \\
\hline Waist circumference & Clear & $\begin{array}{l}\text { Significant decrease in waist circumference can be achieved with } \\
\text { rimonabant within } 9 \text { months }\end{array}$ \\
\hline Lipid profiles & Clear & $\begin{array}{l}\text { Rimonabant is effective in raising HDL-C, lowering triglycerides, and } \\
\text { improving total:HDL and LDL:HDL ratios for up to } 2 \text { years }\end{array}$ \\
\hline
\end{tabular}




\begin{tabular}{|lll|}
\hline $\begin{array}{l}\text {...table continued } \\
\text { Outcome measure }\end{array}$ & Evidence & Implications \\
\hline Metabolic syndrome & Substantial & Rimonabant can reduce the prevalence of metabolic syndrome \\
Adiponectin levels & Substantial & $\begin{array}{l}\text { Rimonabant can increase plasma adiponectin and reduce leptin levels } \\
\text { implying direct metabolic effect }\end{array}$ \\
Blood pressure & Clear & Rimonabant has a neutral effect on blood pressure after 1 year \\
\hline HbA $_{10}$, glycosylated hemoglobin; HDL-C, high-density lipoprotein cholesterol; LDL, low-density lipoprotein. \\
\hline
\end{tabular}

\section{Scope, aims, and objectives}

The increasing worldwide prevalence of obesity and overweight, and the related constellation of risk factors known as the metabolic syndrome (including dyslipidemia, insulin resistance, hypertension, and vascular endothelial dysfunction) are thought to underlie a growing pandemic of cardiovascular disease, diabetes, and certain types of cancer. It is estimated that $90 \%$ of type 2 diabetes cases are directly caused by obesity (James \& Rigby 2004), and between 112000 and 280000 deaths per annum in the USA are attributable to obesity-related disease (Allison et al. 1999; Flegal et al. 2005). In addition to reducing long-term life expectancy, obesity is associated with substantial morbidity, disability, and impairment of quality of life. Comorbidities directly linked with obesity include respiratory difficulties, sleep apnea, infertility, skin disorders, and psychologic dysfunction arising from poor self-esteem (Khaodhiar et al. 1999; Pender \& Pories 2005). Interventions to address obesity include appropriate diet, educational initiatives, and exercise. However, drug therapy may be indicated in patients for whom these measures alone are ineffective.

The multifactorial etiology of obesity has sparked numerous lines of research exploring novel therapeutic targets. One such target is the endocannabinoid system, a neuroendocrine pathway involved in the regulation of reward behavior, appetite, and energy homeostasis. Endocannabinoids have physiologic functions in the central nervous system and peripheral organs such as adipose tissue and gut, involving complex modulation and feedback mechanisms (Di Marzo et al. 2001; Pagotto et al. 2005). Evidence from animal models suggests that overactivity of the endocannabinoid system may be associated with obesity, and that blockade of endocannabinoid CB1 receptors is associated with reductions in food intake and body weight (Kirkham \& Williams 2004). Rimonabant (SR-141716A; Acomplia $^{\circledR}$, Sanofi-Aventis) is a novel CB1 antagonist. This article reviews the evidence of the effectiveness of rimonabant in the treatment of obese or overweight patients, including those with additional cardiovascular risk factors associated with metabolic syndrome.

\section{Methods}

The English language medical literature was reviewed for appropriate articles relating to rimonabant for the treatment of obesity and/or the metabolic syndrome. The search terms used were "rimonabant," "rimonabant AND obesity," "rimonabant AND metabolic syndrome," and "rimonabant AND diabetes." The following databases were searched during July 2005 and then updated in December 2006 as indicated below:

- PubMed, http://www.ncbi.nlm.nih.gov/entrez/query.fcgi

- EMBASE, http://www.datastarweb.com

- BIOSIS, http://www.datastarweb.com

- Database of Abstracts of Reviews of Effects (DARE), National Health Service (NHS) Economic Evaluation Database (NHSEED) Health Technology Assessment (HTA), http://www.york.ac.uk/inst/crd/darehp.htm

- Cochrane Library, http://www3.interscience.wiley.com/cgibin/mrwhome/106568753/HOME

- Clinical Evidence, http://www.clinicalevidence.com

No date restrictions were placed on the above literature searches. Additional searches to identify relevant data presented since 2001 at the annual scientific meetings of the American College of Cardiology, the American Diabetes Association, the American Heart Association, and the European Society of Cardiology were conducted using the search terms outlined above.

The initial search identified 38 full papers and 121 abstracts (defined for the purpose of this article as nonpeer-reviewed literature including abstracts presented at scientific meetings, editorials/opinion articles, and meeting highlights reports). Of the 38 full papers, two publications contained clinical evidence on rimonabant, one randomized controlled trial (RCT) (Van Gaal et al. 2005), and one observational case report (van Oosten et al. 2004). Of the abstracts, 13 publications identified by the initial search contained clinical data on rimonabant. Following removal of duplicates, six abstracts were included from this initial literature search (Table 1).

The PubMed English language literature search was updated on December 12, 2006 with the following limits: publication date August 1, 2005 to December 12, 2006; humans; clinical trial; randomized controlled trial; meta analysis. The updated search revealed four new records, one of which was excluded because it was out of scope. The remaining three records were categorized as level 2 evidence. A level 1 systematic review from 
Table 1 | Evidence base included in the review

\begin{tabular}{|c|c|c|}
\hline \multirow[t]{2}{*}{ Category } & \multicolumn{2}{|c|}{ Number of records } \\
\hline & Full papers & Abstracts ${ }^{a}$ \\
\hline Initial search & 38 & 121 \\
\hline records excluded & 36 & 115 \\
\hline records included & 2 & 6 \\
\hline Additional studies identified & 0 & 0 \\
\hline Search update, new records & 5 & 1 \\
\hline records excluded & 1 & 0 \\
\hline records included & 4 & 1 \\
\hline $\begin{array}{l}\text { Level } 1 \text { clinical evidence } \\
\text { (systematic review, meta analysis) }\end{array}$ & 1 & 1 \\
\hline Level 2 clinical evidence (RCT) & 4 & $6^{\mathrm{b}}$ \\
\hline Level $\geq 3$ clinical evidence & 1 & 0 \\
\hline trials other than $\mathrm{RCT}$ & 0 & 0 \\
\hline case reports & 1 & 0 \\
\hline Economic evidence & 0 & 0 \\
\hline $\begin{array}{l}\text { For definition of levels of evidence, see } \mathrm{E} \\
\text { Core Evidence website. } \\
\text { alncludes abstracts presented at scientifi } \\
\text { articles, and other nonpeer-reviewed liter } \\
\text { included as evidence, it is deemed to be } \\
\text { bDuplication of published data was notec } \\
\text { search. The stated value refers to the nur } \\
\text { recycled data. } \\
\text { RCT, randomized controlled trial. }\end{array}$ & $\begin{array}{l}\text { Information on } \\
\text { tings, meeting re } \\
\text { Where a publica } \\
2 \text { clinical evidenc } \\
\text { ig publications i } \\
\text { f publications a }\end{array}$ & $\begin{array}{l}\text { ack cover or on } \\
\text { inions/highlights } \\
\text { is category is } \\
\text { by the initial } \\
\text { val of duplicated or }\end{array}$ \\
\hline
\end{tabular}

October 18, 2006 was identified in the Cochrane Library. Finally, the abstracts of the International Diabetes Federation 2006 World Diabetes Congress were also searched, yielding a report of a level 2 study.

\section{Disease overview}

\section{Epidemiology}

The obesity pandemic is one of the most challenging public health issues facing the developed world. The World Health Organization estimates that worldwide there are over 1 billion overweight people (WHO 2003), defined as having body mass index $(\mathrm{BMI}) \geq 25 \mathrm{~kg} / \mathrm{m}^{2}$, of whom at least 300 million are clinically obese $\left(\mathrm{BMI} \geq 30 \mathrm{~kg} / \mathrm{m}^{2}\right)$. In the USA, an estimated 97 million people, $65 \%$ of adults and $16 \%$ of children, are overweight or obese (Hedley et al. 2004). These figures are rising alarmingly: in the period from 1999 to 2002, the ageadjusted prevalence of obesity was $31 \%$, an increase of nearly $8 \%$ from 1988 to 1994 (Flegal et al. 2002). In the 1994-2002 Health Survey for England, obesity was present in $20 \%$ and $22 \%$ of adult males and females, respectively, with overweight present in $45 \%$ and $34 \%$. In addition, the prevalence of obesity in children under 11 years of age is increasing, with $9.9 \%$ of children affected in 1995 compared with $13.7 \%$ in 2003 (Jotangia et al. 2005).

There are clear ethnic and gender variations in susceptibility to obesity. Worldwide prevalence varies widely from $7 \%$ in France to $32.8 \%$ in Brazil (Saw \& Rajan 1997), and well over $40 \%$ in some Polynesian populations (IOTF 2007). In the USA, AfricanAmericans, Hispanics, and American Indians or Alaska natives are more likely than whites and Asians or Pacific Islanders to report fair or poor health status, obesity, diabetes, and no physical activity during leisure time (Bolen et al. 2000). Obesity is increasingly associated with poverty, even in developing countries (James 2004). The likelihood of being obese increases up to around 60 years of age, and is greater in females.

Obesity is the most important modifiable risk factor for type 2 diabetes (Hauner 2004) and is a central feature of the metabolic syndrome (Table 2). It is estimated that 47 million Americans, approximately $23 \%$ of the adult population, have the metabolic syndrome (Ford et al. 2002) as defined by the 2001 National Cholesterol Education Program Expert Panel on Detection, Evaluation, and Treatment of High Blood Cholesterol in Adults (NCEP ATP III) (NCEP 2002). The metabolic syndrome, including elevated risk factors such as obesity, dyslipidemia, and insulin resistance, increases the risk of later cardiovascular disease by approximately two-fold and quadruples the risk of developing type 2 diabetes (Meigs 2002). Type 2 diabetes is believed to affect 18 million Americans, of whom around 6 million are undiagnosed (CDC 2003), and is the leading cause of adult blindness, nontraumatic amputations in adults, and end-stage renal disease (Weinstock 2003). Metabolic syndrome greatly increases an individual's risk of atherosclerotic disease, and is a predictor of cardiovascular risk independent of baseline cardiovascular disease or diabetes (Lakka et al. 2002). Obesity and overweight reduce overall life expectancy (Fontaine et al. 2003) and increase the risk of developing coronary heart disease, stroke, peripheral arterial disease, type 2 diabetes, gallbladder disease, osteoarthritis, and cancers of the breast, prostate, colon, and endometrium. It is estimated that life expectancy in the USA will fall in the twenty-first century, the first decline for 200 years, if the current rate of deaths attributable to obesity continues (Olshansky et al. 2005). Respiratory problems, skin disorders, sleep disturbance, and psychosocial issues including stigmatization and discrimination may further impair quality of life in obese people.

\section{Table 2 | Clinical identification of the metabolic syndrome} (NCEP 2002)

\begin{tabular}{|ll|}
\hline Risk factor & Defining level \\
\hline Abdominal obesity, waist circumference & \\
$\quad$ men & $>102 \mathrm{~cm}(>40 \mathrm{in})$ \\
$\quad$ women & $>88 \mathrm{~cm}(>35 \mathrm{in})$ \\
Triglycerides & $\geq 150 \mathrm{mg} / \mathrm{dL}(\geq 1.6 \mathrm{mmol} / \mathrm{L})$ \\
High-density lipoprotein cholesterol & \\
$\quad$ men & $<40 \mathrm{mg} / \mathrm{dL}(<1 \mathrm{mmol} / \mathrm{L})$ \\
$\quad$ women & $<50 \mathrm{mg} / \mathrm{dL}(<1.3 \mathrm{mmol} / \mathrm{L})$ \\
Blood pressure & $\geq 130 / \geq 85 \mathrm{mmHg}$ \\
Fasting glucose & $\geq 110 \mathrm{mg} / \mathrm{dL}(\geq 6.1 \mathrm{mmol} / \mathrm{L})$ \\
\hline Three or more of the above risk determinants are required to make the diagnosis of \\
metabolic syndrome.
\end{tabular}




\section{Etiology}

Obesity, the metabolic syndrome, and type 2 diabetes are a closely related and convergent continuum of disease processes. The primary cause is chronic overconsumption of energy-dense foods coupled with physical inactivity. However, the transition from normal weight to overweight to obesity is progressive, complex, and multifactorial, probably beginning in early fetal development, and governed by myriad interactions between genotype and environment. In individuals who are genetically predisposed to weight gain, chronic imbalance between energy intake and expenditure leads to dysregulation of the homeostatic mechanisms governing metabolism, energy expenditure, and food intake. A range of physiologic and biochemical changes ensues, including adipogenesis (weight gain), insulin resistance, hypertension, decreased adiponectin and high-density lipoprotein cholesterol (HDL-C), and elevated serum glucose, triglycerides (TG), low-density lipoprotein cholesterol (LDL-C), and proinflammatory markers (Meigs et al. 1997; Cottam et al. 2004).

\section{Energy homeostasis: insulin, leptin, and the endocannabinoid system}

A perplexing array of neuroendocrine signaling pathways and feedback loops involving both the central nervous system and peripheral tissues regulate the body's intake, metabolism, storage, and expenditure of energy. For example, in response to leptin and insulin secreted in the periphery, the hypothalamus regulates caloric intake and energy expenditure by activating anorexigenic and adipostatic pathways, reducing food intake, and increasing metabolic rate (De Souza et al. 2005).

Insulin is normally produced and released by pancreatic beta cells in response to hyperglycemia, and functions primarily to facilitate the transport of glucose to the tissues (mainly liver and skeletal muscle cells) from the bloodstream following absorption from food in the intestines. One effect of chronic excessive food intake, coupled with low energy expenditure, is hyperinsulinemia or insulin resistance. This can be viewed as a compensatory upregulation of circulating insulin in response to continued elevated blood glucose and diminished insulin sensitivity, and is a status strongly associated with overweight and obesity. Hyperglycemia follows when hyperinsulinemia cannot be maintained due to a failure of insulin production (Reaven 2005).

Insulin also regulates leptin production by adipocytes (Havel 2000). Leptin is a pleiotropic adipocytokine that regulates appetite and increases metabolic rate, activates sympathetic afferents, and increases blood pressure (Rahmouni et al. 2005). Specific genetic variations in the receptors for leptin have recently been associated with the onset of obesity and type 2 diabetes (Salopuro et al. 2005). Leptin levels in the circulation directly reflect the amount of fat stored in the body, with elevated levels found in obese patients (Considine 2005).

The endocannabinoid system forms part of an orexigenic (foodseeking) pathway involved with the regulation of leptin signaling and energy homeostasis; activation of hypothalamic CB1 receptors by anandamide, sn-2 arachidonylglycerol (2-AG), or cannabis, activates orexigenic behavior (Cota et al. 2003; Pagotto et al. 2005). Under normal conditions, when leptin levels rise, production of central anorexigenic neuropeptides is upregulated, endocannabinoid activity decreases, and the resulting decrease in $\mathrm{CB} 1$ receptor activation reduces appetite and food-seeking behavior (Di Marzo et al. 2001). CB1 receptors located in gut and adipose tissues are also involved in leptin signaling and lipid metabolism. In obese people, a syndrome of "leptin resistance," similar to insulin resistance, has been described to explain the increased circulating levels and decreased responsiveness to leptin (Jequier 2002). An associated reduction in circulating levels of adiponectin, an antiinflammatory adipocytokine, which can be markedly increased by weight loss, has also been identified (Kopp et al. 2005). This relationship suggests that pharmacologic agents directed at the blockade of CB1 receptors may hold promise for the treatment of obesity (Cota et al. 2003; Jbilo et al. 2005; Pagotto et al. 2005).

\section{The metabolic syndrome and type 2 diabetes}

Central (abdominal) obesity is a key feature of the metabolic syndrome; others include insulin resistance, atherogenic dislipidemia, hypertension, a proinflammatory and prothrombotic hemodynamic environment, and vascular endothelial dysfunction (Table 2). In common with obesity, there is a genetic component to the pathogenesis of the metabolic syndrome. However, modifiable environmental factors such as sedentary lifestyle, overconsumption of saturated fats, smoking, and excessive alcohol consumption are implicated in the progression and clustering of risk factors that characterize the metabolic syndrome.

Around $80 \%$ of obese people are insulin resistant, and insulin resistance precedes type 2 diabetes. Defined as functional insulin deficiency, glucose intolerance, and elevated levels of glycosylated hemogobin $\left(\mathrm{HbA}_{1 \mathrm{c}}\right)$ and fasting plasma glucose, type 2 diabetes occurs when the body can no longer supply sufficient insulin to service the needs of its insulin-resistant tissues, because of progressive beta-cell dysfunction and increasing magnitude of insulin resistance (Gerich 2003). The chronic failure to maintain glycemic control arising from type 2 diabetes causes oxidative stress and activates pathogenic cascades in multiple tissues including the vasculature, kidneys, and central and peripheral nervous systems (Sheetz \& King 2002; Yamagishi \& Imaizumi 2005), resulting in diabetic complications such as neuropathies and end-stage renal disease, and aggravating existing cardiovascular disease.

Debate continues over the key etiologic process driving this pathology (Zimmet et al. 1999; Nesto 2004; Trayhurn 2005; Ziegler 2005). It is uncertain whether the early trigger is insulin resistance or a chronic inflammatory response to increased circulating leptin and reduced adiponectin. However, it is clear that obesity, metabolic syndrome, and type 2 diabetes are progressive, convergent effects of a chronic energy imbalance. Recognition is increasing that interventions to treat and prevent future cardiovascular disease should address this "common soil" etiology. 


\section{Burden of disease}

The burden of obesity and diabetes in terms of economic and quality of life outcomes is substantial. An estimated $5.7 \%$ of total US healthcare expenditure is attributable to patients with BMI $>30 \mathrm{~kg} / \mathrm{m}^{2}$ (Wolf \& Colditz 1998). In 1998, the estimated direct healthcare expenditure on obesity in the USA (including preventive, therapeutic, and diagnostic costs) was $\$$ US78.5 billion (CDC 2005). In 2002, an estimated $€ 328$ billion was spent by the member states of the European Union on direct and indirect costs attributed to obesity (Fry \& Finley 2005). Other factors that contribute to the social and economic burden of obesity as annual event rates in the USA include: 40 million workdays of productivity lost, 63 million doctors' office visits made, 239 million restricted activity days, and 90 million bedbound days (Wellman \& Friedberg 2002). Health-related quality of life is negatively correlated with BMI (Larsson et al. 2002); people who are overweight or obese may encounter psychosocial difficulties including discrimination and stigmatization, and suffer from psychologic distress such as depression and low selfesteem. In 2002, the total cost in the USA of diabetes, a condition closely linked with obesity and with high treatment costs, was estimated at \$US132 billion, of which \$US90 billion were direct healthcare costs (CDC 2003). However, this estimate is considered to be conservative (Hogan et al. 2003).

\section{Current therapy options}

First-line intervention for weight loss and obesity management should involve diet modification and increased physical activity in the context of continued nurse or physician counseling and support. However, where these measures fail to produce satisfactory weight loss (an appropriate treatment goal is $10 \%$ loss of initial weight in 6 months), drug therapy may be warranted. The US National Institutes of Health has issued guidelines for the treatment of obesity, which recommend that all obese adults (BMI $>30 \mathrm{~kg} / \mathrm{m}^{2}$ ) and all adults with a BMI $>27 \mathrm{~kg} / \mathrm{m}^{2}$ with concomitant risk factors should be considered for drug therapy with an agent licensed for weight loss (NIH 1998). Morbidly obese adults (BMI $>40 \mathrm{~kg} / \mathrm{m}^{2}$ ) and all adults with a BMl of $\geq 35 \mathrm{~kg} / \mathrm{m}^{2}$ and concomitant risk factors are candidates for bariatric surgery. Guidelines from the National Institute for Health and Clinical Excellence (NICE) in England and Wales are identical except that orlistat is indicated in patients with a BMl $\geq 28 \mathrm{~kg} / \mathrm{m}^{2}$ plus additional risk factors (NICE 2006).

To date, no long-term prospective studies have demonstrated that weight reduction in obese patients reduces mortality (Cerulli \& Malone 1998); yet, as mentioned above, obesity and overweight reduce overall life expectancy. However, effective weight management (reduction of $5-10 \%$ of initial body weight), provided it can be maintained, can lead to clinically meaningful benefits, and reduce the presence and future risk of obesity-related complications. Effective weight management can improve glycemic control, hypertension, and lipid profiles in addition to other benefits (Valsamakis et al. 2002). Treatment modalities include diet and behavior modification, exercise, and, where indicated, pharmacologic intervention. Orlistat and sibutramine are currently approved in Europe and the USA for the treatment of obesity (Table 3), but both seem modestly effective in the long term. Moreover, several product withdrawals and licensing restrictions in recent years have reduced the therapeutic options available for weight loss. Drugs licensed for other indications, which may also promote weight loss, include bupropion, exenatide, fluoxetine, metformin, topiramate, and zonisamide (Kaplan 2005; Snow et al. 2005); used according to their respective licensed labeling, such products may facilitate weight loss as a secondary effect, but cannot be recommended as specific interventions for obesity management.

\begin{tabular}{|c|c|c|c|}
\hline Drug class & $\begin{array}{l}\text { Potential adverse } \\
\text { effects }\end{array}$ & Advantages & Disadvantages \\
\hline \multicolumn{4}{|c|}{ Gastrointestinal lipase inhibitor } \\
\hline Orlistat & $\begin{array}{l}\text { Gastrointestinal } \\
\text { side effects }\end{array}$ & $\begin{array}{l}\text { Minimal } \\
\text { bioabsorption; no } \\
\text { central nervous } \\
\text { system effects. } \\
\text { Possible metabolic } \\
\text { benefits beyond } \\
\text { weight loss }\end{array}$ & $\begin{array}{l}\text { Limited tolerability; } \\
\text { fat-soluble vitamin } \\
\text { supplements may } \\
\text { be required }\end{array}$ \\
\hline \multicolumn{4}{|c|}{ Norepinephrine/serotonin reuptake inhibitor } \\
\hline Sibutramine & $\begin{array}{l}\text { Hypertension, } \\
\text { tachycardia, } \\
\text { palpitations }\end{array}$ & $\begin{array}{l}\text { Possible metabolic } \\
\text { benefits beyond } \\
\text { weight loss }\end{array}$ & $\begin{array}{l}\text { Requires blood } \\
\text { pressure } \\
\text { monitoring; should } \\
\text { not be prescribed } \\
\text { in patients with } \\
\text { uncontrolled or } \\
\text { poorly controlled } \\
\text { hypertension }\end{array}$ \\
\hline \multicolumn{4}{|c|}{ Sympathomimetic } \\
\hline Phentermine & $\begin{array}{l}\text { Hypertension, } \\
\text { tachycardia, } \\
\text { palpitations, dry } \\
\text { mouth, constipation, } \\
\text { dizziness }\end{array}$ & $\begin{array}{l}\text { Effective in short- } \\
\text { term weight loss }\end{array}$ & $\begin{array}{l}\text { Only indicated for } \\
\text { short-term use; } \\
\text { tolerance may } \\
\text { develop }\end{array}$ \\
\hline
\end{tabular}

\section{Orlistat}

Orlistat promotes weight loss by inhibiting the absorption of dietary fat. A potent gastrointestinal lipase inhibitor, orlistat reduces dietary fat absorption from the digestive tract by up to $30 \%$, reducing caloric intake by up to $200 \mathrm{kcal} /$ day (Harp 1999). The main adverse effects of orlistat are gastrointestinal disturbances related to increased levels of fat in the stools.

The efficacy and safety of orlistat over 4 years of treatment were demonstrated in a placebo-controlled, randomized trial-the longest yet reported for a weight loss intervention (Torgerson et al. 2004). Orlistat also appears to offer metabolic benefits beyond weight loss alone, improving serum lipid, glucose, and insulin parameters (Davidson et al. 1999; Muls et al. 2001; Hanefeld \& Sachse 2002). Orlistat therapy may cause a deficiency in fatsoluble vitamins that may be overcome by dietary supplementation. Gastrointestinal adverse effects, which include oily spotting, flatus with discharge, oily evacuation, fecal 
incontinence, and increased defecation, affect up to $25 \%$ of patients in the first year of treatment, and may limit the therapeutic utility of orlistat.

\section{Sibutramine}

Sibutramine is a centrally active appetite suppressant (anorexigenic). A norepinephrine and serotonin reuptake inhibitor, sibutramine increases satiety and reduces appetite, and may increase energy expenditure by thermogenesis (Luque \& Rey 2002). Sibutramine is associated with elevations in blood pressure in some patients, which necessitates clinical monitoring, and treatment must be discontinued if sustained elevations are noted.

A Health Technology Assessment by NICE concluded that the statistically significant changes in weight relative to placebo demonstrated in trials of sibutramine might not always translate into clinically meaningful benefits (NICE 2001). Nonetheless, sibutramine is also associated with improvements in various metabolic parameters including insulin resistance, glucose, and lipid profiles in obese people with and without type 2 diabetes (Tankova et al. 2004), and in obese individuals with controlled hypertension (McMahon et al. 2000). Adverse effects associated with sibutramine include hypertension and tachycardia; sibutramine is therefore contraindicated in patients with uncontrolled or poorly controlled hypertension. It should not be used for more than 1 year.

\section{Unmet needs}

Overweight and obesity are chronic conditions that require longterm treatment; however, physicians are reluctant to treat obesity despite the rapid increase in its prevalence (Kopelman 1999). This may be due in part to the modest effectiveness and safety and tolerability issues associated with current therapeutic options, and the lack of evidence for their impact on long-term morbidity and mortality outcomes. In addition, the number of therapeutic options for obesity has decreased in recent years, largely due to safety concerns. Fenfluramine and dexfenfluramine were withdrawn worldwide in 1997 after being linked to primary pulmonary hypertension and heart valve abnormalities. Phenylpropanolamine, an agent with weightreducing effects used as an ingredient in many over-the-counter medications, was withdrawn from the USA in 2000 because of concerns it may cause hemorrhagic stroke. Phentermine and amfepramone were withdrawn from Europe in 2001 because risks were deemed to outweigh benefits, and phentermine is licensed in the USA only for short-term weight loss. There is therefore a clear need for safer and more effective treatment options. The ideal profile of a new weight-reduction therapy should deliver clinically relevant weight reduction and long-term weight maintenance without adverse effects or the necessity for clinical monitoring.

Given the growing prevalence of obesity, the long-term nature of treatment, and the difficulties many patients experience in maintaining weight loss, there is a need to identify individuals likely to benefit most from pharmacologic intervention.
Significant improvement in metabolic abnormalities following weight loss is seen only in insulin-resistant obesity (Reaven et al. 2004); such patients, who represent around $80 \%$ of the obese population, may be the most appropriate group at which to target more intensive weight-management efforts.

A further unmet need relates to the ways outcomes in obesity management are measured and reported. There is limited scope for monitoring patient compliance with dietary interventions or recommendations. In particular, clinicians have no means of verifying patients' actual daily caloric intake. Validated instruments to monitor variability in compliance should therefore be a priority in the clinical development of new weight loss products.

\section{Clinical evidence with rimonabant}

Rimonabant is a novel compound which has been shown to block endocannabinoid CB1 receptors, reduce food intake, and promote weight loss in animal and human studies (Kirkham \& Williams 2001; Williams \& Kirkham 2002; Fernandez \& Allison 2004; Jbilo et al. 2005; Poirier et al. 2005). In phase II studies of up to 16 weeks' duration, rimonabant showed a dosedependent effect on weight reduction and, compared with placebo, was associated with significant reductions in hunger and weekly carbohydrate consumption (Fernandez \& Allison 2004).

A phase III clinical development program of rimonabant in obesity (RIO), has evaluated the effects of rimonabant on weight loss, weight maintenance, and metabolic variables in four placebo-controlled, randomized trials involving approximately 6600 patients (Table 4). Outcomes measured in these trials include

\begin{tabular}{|c|c|c|c|}
\hline Study & Duration & Main outcome(s) & $\begin{array}{l}\text { Patient } \\
\text { population (n) }\end{array}$ \\
\hline RIO-Europe & 2 years & $\begin{array}{l}\text { Weight reduction } \\
\text { Lipid profiles } \\
\text { Glycemic control } \\
\text { Metabolic syndrome status }\end{array}$ & $\begin{array}{l}\text { Obese or overweight } \\
\text { with or without } \\
\text { comorbidities, } \\
\text { except diabetes } \\
\text { (1507) }\end{array}$ \\
\hline $\begin{array}{l}\text { RIO- } \\
\text { Diabetes }\end{array}$ & 1 year & $\begin{array}{l}\text { Weight reduction } \\
\mathrm{HbA}_{1 \mathrm{c}} \\
\text { Metabolic syndrome status }\end{array}$ & $\begin{array}{l}\text { Obese or overweight } \\
\text { with type } 2 \text { diabetes } \\
\text { (1047) }\end{array}$ \\
\hline RIO-Lipids & 1 year & $\begin{array}{l}\text { Weight reduction } \\
\text { Lipid profiles } \\
\text { C-reactive protein } \\
\text { Metabolic syndrome status }\end{array}$ & $\begin{array}{l}\text { Obese or overweight } \\
\text { with untreated } \\
\text { dyslipidemia, } \\
\text { diabetes excluded } \\
\text { (1033) }\end{array}$ \\
\hline $\begin{array}{l}\text { RIO-North } \\
\text { America }\end{array}$ & $\begin{array}{l}1+ \\
1 \text { yeara }^{a}\end{array}$ & $\begin{array}{l}\text { Weight reduction } \\
\text { Weight maintenance } \\
\text { Lipid profiles } \\
\text { Glycemic control } \\
\text { Metabolic syndrome status }\end{array}$ & $\begin{array}{l}\text { Obese or overweight } \\
\text { with or without } \\
\text { comorbidities, } \\
\text { except diabetes } \\
(3040)\end{array}$ \\
\hline
\end{tabular}


Table 5 | Effect of rimonabant on bodyweight indices in randomized controlled trials

\begin{tabular}{|c|c|c|c|c|c|c|c|}
\hline \multirow[t]{2}{*}{ Study } & \multirow[t]{2}{*}{ Reference } & \multirow{2}{*}{$\begin{array}{l}\text { Drugs and } \\
\text { dosage (n) }\end{array}$} & \multirow[t]{2}{*}{ Duration } & \multicolumn{4}{|c|}{ Outcome } \\
\hline & & & & $\begin{array}{l}\text { Weight reduction } \\
\text { (kg) }\end{array}$ & $\begin{array}{l}\text { Waist reduction } \\
\text { (cm) }\end{array}$ & $\begin{array}{l}\text { Patients } \\
\text { achieving weight } \\
\text { loss } \geq 5 \%(\%)\end{array}$ & $\begin{array}{l}\text { Patients } \\
\text { achieving weight } \\
\text { loss } \geq 10 \%(\%)\end{array}$ \\
\hline \multirow[t]{3}{*}{ RIO-Lipids } & \multirow{3}{*}{$\begin{array}{l}\text { Deprés et al. } \\
2005 a\end{array}$} & $\operatorname{Rim} 5$ (340) & \multirow[t]{3}{*}{1 year } & $4.2^{\mathrm{a}}$ & 4.9 & NR & NR \\
\hline & & Rim 20 (344) & & $8.6^{a}$ & $9.1^{a}$ & $58.4^{a}$ & $32.6^{a}$ \\
\hline & & Pla (334) & & 2.3 & 3.4 & 19.5 & 7.2 \\
\hline \multirow[t]{3}{*}{ RIO-Europe } & \multirow{3}{*}{$\begin{array}{l}\text { Van Gaal et al. } \\
2005\end{array}$} & Rim 5 (603) & \multirow[t]{3}{*}{1 year } & 3.4 & 3.9 & $33.2^{a}$ & 10.1 \\
\hline & & Rim 20 (599) & & $6.6^{a}$ & $6.5^{a}$ & $50.9^{a}$ & $27.4^{a}$ \\
\hline & & Pla (305) & & 1.8 & 2.4 & 19.2 & 7.3 \\
\hline \multirow[t]{2}{*}{ SERENADE } & \multirow{2}{*}{$\begin{array}{l}\text { Iranmanesh et al. } \\
(2006)\end{array}$} & Rim 20 & \multirow[t]{2}{*}{6 months } & $6.7^{b}$ & $6^{b}$ & NR & NR \\
\hline & & Pla & & 2.8 & 2 & NR & NR \\
\hline \multirow{3}{*}{$\begin{array}{l}\text { RIO- } \\
\text { North America }\end{array}$} & \multirow{3}{*}{$\begin{array}{l}\text { Pi-Sunyer et al. } \\
2006\end{array}$} & Rim 5 (1191) & \multirow[t]{3}{*}{1 year } & $1.8^{\mathrm{a}, \mathrm{c}}$ & $0.9^{c}$ & 26.1 & 10.6 \\
\hline & & Rim 20 (1189) & & $5.9^{\mathrm{a}, \mathrm{c}}$ & $4.5^{\mathrm{a}, \mathrm{c}}$ & 48.6 & $25.2^{a}$ \\
\hline & & Pla (590) & & $0^{c}$ & $0^{c}$ & 20 & 8.5 \\
\hline \multirow[t]{3}{*}{ RIO-Diabetes } & \multirow[t]{3}{*}{ Scheen et al. 2006} & $\operatorname{Rim} 5$ (358) & \multirow[t]{3}{*}{1 year } & 2.3 & 2.9 & 21.7 & 6.2 \\
\hline & & Rim 20 (339) & & $5.3^{b, d}$ & $5.2^{b, d}$ & $49.4^{b, d}$ & $16.4^{b, d}$ \\
\hline & & Pla (348) & & 1.4 & 1.9 & 14.5 & 2.0 \\
\hline
\end{tabular}

absolute and percentage weight loss; change in waist circumference; changes in serum cholesterol levels, glycemic parameters, blood pressure, and metabolic syndrome status; quality of life; and safety and tolerability.

All four RIO trials followed a similar design. After screening, a hypocaloric diet (reduced by $600 \mathrm{kcal} /$ day) was prescribed in conjunction with a 4-week placebo run-in. Patients were then randomized $2: 2: 1$ to rimonabant 5 or $20 \mathrm{mg} /$ day or placebo. In the RIO-North America trial, patients were rerandomized after 1 year to evaluate the effect of rimonabant on weight maintenance for up to 2 years.

Data from all four RIO trials have been published in full (Deprés et al. 2005; Van Gaal et al. 2005; Pi-Sunyer et al. 2006; Scheen et al. 2006). Other RIO data have been presented at symposia or as latebreaking abstracts at various scientific meetings (Anon. 2004a-c, 2005; Cleland et al. 2004; Mator 2004; NHSC 2004; Susman 2004; Després et al. 2005b; Faxon et al. 2005; Gomaraschi 2005; Rosenstock 2005; Shah et al. 2005). The Cochrane Collaboration review of rimonabant included published data from RIO-Lipids, RIO-Europe, and RIO-North America, and unpublished data from RIO-Diabetes (Curioni \& André 2006). The review provided level 1 evidence on changes in bodyweight, waist circumference, TG, HDL-C, blood pressure, and incidence of adverse effects.

\section{Weight reduction}

There is clear level 1 evidence from the Cochrane meta analysis that rimonabant $20 \mathrm{mg} /$ day causes a significant mean reduction in bodyweight of $4.6 \mathrm{~kg}$ compared with placebo after 1 year's treatment (Curioni \& André 2006). The corresponding value for rimonabant $5 \mathrm{mg} /$ day was $1.3 \mathrm{~kg}$; the pooled effect of the
$20 \mathrm{mg}$ dose was $3.3 \mathrm{~kg}$. The value used for bodyweight reduction with rimonabant $20 \mathrm{mg}$ from $\mathrm{RIO}$-Lipids in the meta analysis was a last observation carried forward of $6.9 \mathrm{~kg}$; this study also reported a mean reduction of $8.6 \mathrm{~kg}$ using a post-hoc, repeatedmeasures approach, which the authors considered to be more representative of the effects of the drug (Després et al. 2005a) (Table 5). Van Gaal et al. (2005) reported an identical mean weight loss in the 363 patients who completed 12 months of treatment with rimonabant $20 \mathrm{mg} /$ day. Weight loss with rimonabant $20 \mathrm{mg}$ occurred in the first 9 months of treatment and then stabilized up to 12 months (Després et al. 2005a). In 256 patients receiving rimonabant $20 \mathrm{mg} /$ day for 2 years, mean weight loss was maintained at $7.4 \mathrm{~kg}$ (Pi-Sunyer et al. 2006).

The proportions of patients achieving $5 \%$ and $10 \%$ loss of initial body weight, generally considered to be the range of a clinically meaningful treatment target, followed similar trends to weight loss (Table 5). Between $21.7 \%$ and $33.2 \%$ of patients on rimonabant $5 \mathrm{mg} /$ day and $49.4 \%$ to $58.4 \%$ on $20 \mathrm{mg}$ /day achieved $5 \%$ weight loss, but for $10 \%$ weight loss, only rimonabant $20 \mathrm{mg}$ was consistently statistically superior to placebo $(16.4 \%$ to $32.6 \%$ achieved target). Again, the effect was maintained for 2 years, with $40 \%$ maintaining a $5 \%$ weight reduction and $17 \%$ maintaining a $10 \%$ reduction with rimonabant $20 \mathrm{mg} /$ day (Pi-Sunyer et al. 2006).

The Cochrane meta analysis indicates that waist circumference, which is thought to provide a more accurate anthropometric measure of future cardiovascular risk than BMI (Zhu et al. 2002), was significantly reduced in patients randomized to rimonabant 5 or $20 \mathrm{mg}$ compared with placebo (mean change in waist circumference 1.2 and $3.8 \mathrm{~cm}$, respectively; $P<0.00001$ ) (Curioni \& André 2006). The maximum waist circumference reduction was achieved after 9 months of treatment, after which it remained 
constant, mirroring the effect on bodyweight (Després et al. 2005a).

The effects of rimonabant on weight and waist circumference were independent of baseline demographics including gender. In severely obese patients (BMI $\geq 40 \mathrm{~kg} / \mathrm{m}^{2}$ ), weight reduction was reported to be comparable to the overall study population (Van Gaal et al. 2005); however, data to support this were not presented.

Adherence to the dietary protocol in RIO-Europe has been called into question. The reported magnitude of weight loss in the placebo-treated patients is smaller than that which would be expected to result following a diet reduced by $\sim 600 \mathrm{kcal} /$ day for 1 year (Esposito \& Giugliano 2005); the implication is that some patients may not have complied with the dietary requirements of the study, potentially confounding the results in favor of rimonabant. Measuring food intake and dietetic compliance in obesity research has been identified as a problem (Winkler 2005).

\section{Lipid profiles}

Pooled data from the Cochrane meta analysis indicates a significant reduction of $19.8 \mathrm{mg} / \mathrm{dL}$ in plasma TG and an increase of $3.5 \mathrm{mg} / \mathrm{dL}$ in HDL-C following 1 year's treatment with rimonabant $20 \mathrm{mg} /$ day (Curioni \& André 2006). The $5 \mathrm{mg} /$ day dose was also associated with a smaller, but significant, increase of $1.3 \mathrm{mg} / \mathrm{dL}$. Rimonabant significantly improves ratios of LDL: HDL and total cholesterol: HDL-C because of its lack of effect on total cholesterol or LDL-C (Table 6). HDL-C levels continued to increase during long-term treatment with rimonabant $20 \mathrm{mg} /$ day, with a mean rise of $9.5 \%$ compared with placebo after 2 years in 253 patients $(P<0.001)$ (Pi-Sunyer et al.
2006). The decrease in TG was also sustained over 2 years, falling by $7.4 \%$ compared with placebo.

The RIO-Lipids trial was specifically designed to investigate the effect of rimonabant on cardiovascular risk factors in overweight or obese patients with dyslipidemia, defined as TG 1.7 to $7.9 \mathrm{mmol} / \mathrm{L}$, and total: HDL-C ratio $>5$ for men and $>4.5$ for women (Després et al. 2005a). TG, LDL: HDL ratio, and total: HDL-C ratio decreased significantly, and HDL-C increased significantly after 1 year's treatment with rimonabant $20 \mathrm{mg}$ /day compared with placebo (Table 6). LDL-C levels were not significantly decreased during treatment with rimonabant $20 \mathrm{mg} /$ day, but the peak size of LDL particles was greater and there were fewer small particles (Després et al. 2005a).

There was also a substantial degree of baseline dyslipidemia, defined as HDL-C $<1.03 \mathrm{mmol} / \mathrm{L}, \mathrm{LDL}-\mathrm{C} \geq 3.36 \mathrm{mmol} / \mathrm{L}$, and TG $\geq 1.69 \mathrm{mmol} / \mathrm{L}$, in the RIO-Europe study population ( $60.8 \%$ overall) (Van Gaal et al. 2005). To examine the possibility of a weight loss independent effect of rimonabant on lipid variables, logistic regression models and/or analysis of covariance (ANCOVA) were applied, using weight loss as the covariate. These analyses provide estimates suggesting that only $60 \%$ of the increase in HDL-C and $45 \%$ of the reduction in TG could be explained by the observed weight loss; the remaining between-group differences are presumably exerted through an undefined effect of rimonabant on lipid metabolism.

Whether the magnitude of the effects of rimonabant on lipid parameters is sufficient to have implications for long-term patient outcomes remains to be seen; however, the direction of change in these variables is associated with reduced progression of atherogenic and proinflammatory processes. The authors of RIOEurope calculate that the placebo-subtracted benefit of

Table 6 | Effect of rimonabant on lipid profiles (values are percentage change from baseline unless otherwise specified)

\begin{tabular}{|c|c|c|c|c|c|c|c|c|c|}
\hline \multirow[t]{2}{*}{ Study } & \multirow[t]{2}{*}{ Reference } & \multirow{2}{*}{$\begin{array}{l}\text { Drugs and } \\
\text { dosage }(n)\end{array}$} & \multirow[t]{2}{*}{ Duration } & \multicolumn{6}{|c|}{ Outcome } \\
\hline & & & & TC & TG & LDL-C & HDL-C & LDL:HDL & TC:HDL \\
\hline \multirow[t]{3}{*}{ RIO-Lipids } & \multirow{3}{*}{$\begin{array}{l}\text { Deprés et al. } \\
2005 a\end{array}$} & $\operatorname{Rim} 5$ (340) & \multirow[t]{3}{*}{1 year } & +2.3 & 0 & +4.8 & +15.6 & -0.31 & -0.57 \\
\hline & & Rim 20 (344) & & +2.2 & $-15.8^{a}$ & +8.4 & $+23.4^{\mathrm{a}}$ & $-0.41^{a}$ & $-0.84^{a}$ \\
\hline & & Pla (334) & & +1.4 & -3.6 & +6.1 & +12.2 & -0.19 & -0.5 \\
\hline \multirow[t]{3}{*}{ RIO-Europe } & \multirow{3}{*}{$\begin{array}{l}\text { Van Gaal et al. } \\
2005\end{array}$} & Rim 5 (603) & \multirow[t]{3}{*}{1 year } & $+0.06^{b}$ & $-0.02^{b}$ & $+0.13^{b}$ & $+0.19^{b}$ & NR & $-0.52^{b}$ \\
\hline & & Rim 20 (599) & & $+0.05^{b}$ & $-0.2^{a, b}$ & $+0.08^{b}$ & $+0.26^{a, b}$ & $N R$ & $-0.71^{a, b}$ \\
\hline & & Pla (305) & & $+0.08^{b}$ & $-0.01^{b}$ & $+0.17^{\mathrm{b}}$ & $+0.15^{\mathrm{b}}$ & $N R$ & $-0.42^{\mathrm{b}}$ \\
\hline \multirow[t]{2}{*}{ SERENADE } & \multirow{2}{*}{$\begin{array}{l}\text { Iranmanesh et al. } \\
(2006)\end{array}$} & $\operatorname{Rim} 20$ & \multirow[t]{2}{*}{6 months } & NR & -16.3 & NR & +10.1 & NR & NR \\
\hline & & $\mathrm{Pla}$ & & NR & +4.4 & NR & +3.2 & NR & NR \\
\hline \multirow{3}{*}{$\begin{array}{l}\text { RIO- } \\
\text { North America }\end{array}$} & \multirow{3}{*}{$\begin{array}{l}\text { Pi-Sunyer et al. } \\
2006\end{array}$} & Rim 5 (1191) & \multirow[t]{3}{*}{1 year } & $N R$ & $-6.6^{c}$ & NR & $+2.4^{\mathrm{c}}$ & $N R$ & $-0.15^{a, c}$ \\
\hline & & $\operatorname{Rim} 20$ (1189) & & NR & $-16.1^{\mathrm{a}, \mathrm{c}}$ & NR & $+8.6^{a, c}$ & NR & $-0.32^{\mathrm{a}, \mathrm{c}}$ \\
\hline & & Pla (590) & & NR & $0^{c}$ & NR & $0^{c}$ & NR & $0^{c}$ \\
\hline \multirow[t]{3}{*}{ RIO-Diabetes } & \multirow{3}{*}{$\begin{array}{l}\text { Scheen et al. } \\
2006^{d}\end{array}$} & Rim 5 (358) & \multirow[t]{3}{*}{1 year } & +3.3 & +1.3 & +7.5 & +9.2 & $N R$ & -0.23 \\
\hline & & Rim 20 (339) & & +3.3 & $-9.1^{e}$ & +6.9 & $+15.4^{e}$ & NR & $-0.51^{e}$ \\
\hline & & Pla (348) & & +3.3 & +7.3 & +7.2 & +7.1 & NR & -0.16 \\
\hline
\end{tabular}




\begin{tabular}{|c|c|c|c|c|c|c|c|}
\hline Study & Reference & $\begin{array}{l}\text { Drugs and } \\
\text { dosage }(n)\end{array}$ & Duration & $\begin{array}{l}\text { Fasting glucose } \\
\text { (mmol/L) }\end{array}$ & $\mathrm{HbA}_{1 \mathrm{c}}(\%)$ & $\begin{array}{l}\text { Fasting insulin } \\
(\mathrm{mcU} / \mathrm{mL})\end{array}$ & HOMA-IR \\
\hline \multirow[t]{3}{*}{ RIO-Lipids } & \multirow{3}{*}{$\begin{array}{l}\text { Deprés et al. } \\
2005 a\end{array}$} & $\operatorname{Rim} 5$ (340) & \multirow[t]{3}{*}{1 year } & +0.01 & NR & +0.6 & NR \\
\hline & & Rim 20 (344) & & -0.09 & NR & -1.3 & NR \\
\hline & & Pla (334) & & -0.02 & NR & +0.7 & NR \\
\hline \multirow{2}{*}{ RIO-Europe } & \multirow{2}{*}{$\begin{array}{l}\text { Van Gaal et al. } \\
2005\end{array}$} & Rim 20 (599) & \multirow{2}{*}{1 year } & -0.09 & NR & $-1.0^{a}$ & -0.3 \\
\hline & & Pla (305) & & +0.03 & NR & +1.8 & +0.4 \\
\hline \multirow[t]{2}{*}{ SERENADE } & \multirow{2}{*}{$\begin{array}{l}\text { Iranmanesh et al. } \\
(2006)\end{array}$} & $\operatorname{Rim} 20$ & \multirow[t]{2}{*}{6 months } & NR & $-0.8^{\mathrm{b}}$ & NR & NR \\
\hline & & $\mathrm{Pla}$ & & NR & -0.3 & NR & NR \\
\hline $\begin{array}{l}\text { RIO- } \\
\text { North America }\end{array}$ & $\begin{array}{l}\text { Pi-Sunyer et al. } \\
2006\end{array}$ & $\operatorname{Rim} 5$ (1191) & 1 year & $-0.31 \mathrm{mg} / \mathrm{dL}^{\mathrm{c}, \mathrm{d}}$ & NR & $-1.7^{\mathrm{d}}$ & $-0.6^{d}$ \\
\hline \multirow{2}{*}{ RIO-Diabetes } & \multirow{2}{*}{ Scheen et al. $2006^{e}$} & Rim 20 (339) & \multirow{2}{*}{1 year } & $-0.64^{f}$ & $-0.6^{f}$ & -0.7 & -0.5 \\
\hline & & Pla (348) & & +0.33 & +0.1 & +0.4 & +0.6 \\
\hline
\end{tabular}

rimonabant on HDL-C increase is approximately $10 \%$ (Van Gaal et al. 2005). This is considered to be promising given that small HDL-C increases incrementally reduce future cardiovascular risk (Gordon et al. 1989). The favorable changes in HDL-C and TG appear to be approximately double what could be attributed to weight loss (Pi-Sunyer et al. 2006), indicating a direct effect on lipid metabolism. The weight loss-independent effect of rimonabant has been postulated as being due to increased mRNA expression of adiponectin by peripheral adipose tissues, leading to beneficial improvements in fatty-acid oxidation (Van Gaal et al. 2005). An analysis of adiponectin levels in RIO-Lipids (Després et al. 2005a) has reported significant increases in plasma adiponectin of $2.7 \mathrm{mcg} / \mathrm{mL}$ following treatment for up to 1 year with rimonabant $20 \mathrm{mg}(P<0.001$ vs placebo). The increases positively correlated with HDL-C, and $57 \%$ of the increase was weight loss independent.

\section{Glycemic control}

Rimonabant $20 \mathrm{mg} /$ day for up to 1 year showed beneficial effects on glycemic parameters including serum levels of fasting glucose and insulin, $\mathrm{HbA}_{1 \mathrm{c}}$, and insulin resistance in obese and overweight patients (Table 7). These benefits appear to stem from stabilization of the declining glycemic control normally associated with obesity. As with lipids, the beneficial changes of rimonabant on fasting insulin, insulin resistance, and $\mathrm{HbA}_{1 \mathrm{c}}$, are roughly twice what could be predicted from weight loss, suggesting a direct effect on glucose metabolism.

A pooled subgroup analysis of 1-year data from patients in RIO-Lipids, RIO-Europe, and RIO-North America with impaired fasting glucose (IFG) or "prediabetes," defined as fasting glucose of $100-125 \mathrm{mg} / \mathrm{dL}$ (5.56-6.94 mmol/L), reported significant differences in weight loss relative to placebo for both
5 and $10 \mathrm{mg}$ rimonabant in the intention-to-treat population (Rosenstock 2005). Significant improvements relative to placebo were also noted in lipid profiles, fasting insulin levels, and homeostasis model assessment-insulin resistance (HOMA$\mathrm{IR}$ ) in patients treated with rimonabant $20 \mathrm{mg}$. Nonsignificant trends favoring rimonabant were noted in the proportions of patients with IFG, normal fasting glucose, and type 2 diabetes after 1 year's treatment.

RIO-Diabetes studied the effects of rimonabant in overweight or obese patients with type 2 diabetes receiving metformin or a sulfonylurea (Scheen et al. 2006). There were significant decreases in fasting glucose, fasting insulin, $\mathrm{HbA}_{1 \mathrm{c}}$, as well as insulin resistance with rimonabant $20 \mathrm{mg} /$ day (Table 7). Sixty-eight percent of patients taking rimonabant $20 \mathrm{mg} /$ day achieved a target $\mathrm{HbA}_{1 \mathrm{c}}$ level of $<7 \%$ compared with $48 \%$ of placebo recipients $(P<0.0001)$, and $43 \%$ achieved a level $<6.5 \%$ versus $21 \%$ on placebo $(P<0.0001)$. $\mathrm{HbA}_{1 \mathrm{c}}$ was not affected by concomitant metformin or sulfonylureas. Dosages of other antidiabetic drugs were increased in $11.3 \%$ and $12.8 \%$ of patients taking rimonabant $20 \mathrm{mg} /$ day and placebo, respectively, and decreased in $11.9 \%$ and $7.5 \%$ of patients.

Similarly, mean $\mathrm{HbA}_{1 \mathrm{c}}$ was reduced by $0.8 \%$ after 6 months in treatment-naïve patients with type 2 diabetes receiving rimonabant $20 \mathrm{mg} /$ day compared with $0.3 \%$ with placebo (Iranmanesh et al. 2006).

\section{The metabolic syndrome}

RIO-Europe, RIO-North America, RIO-Lipids, and RIO-Diabetes provide good evidence that rimonabant $20 \mathrm{mg}$ may significantly reduce the incidence of the metabolic syndrome in obese patients 
(Table 8). This is encouraging given the high prevalence of the metabolic syndrome in this population, and suggests that rimonabant could potentially reduce the burden of risk factor management in obesity.

\begin{tabular}{|lllll|}
\hline Table 8 | Effect of rimonabant on prevalence of the metabolic \\
syndrome ${ }^{\mathrm{a}}$
\end{tabular}

The prevalence of the metabolic syndrome [defined by NCEP ATP III criteria (Table 2)] decreased in all patients after 1 year's treatment. However, the reduction was significant with rimonabant $20 \mathrm{mg} /$ day versus placebo. The difference between rimonabant $5 \mathrm{mg}$ and placebo did not reach statistical significance for this outcome.

These findings suggest that rimonabant $20 \mathrm{mg}$ may produce clinically meaningful reductions in obese patients presenting with the metabolic syndrome, with consequent implications for risk factor management and improvements in prognosis. The reduction in the metabolic syndrome appears to be a result of the decrease in waist circumference and increase in HDL-C (Després et al. 2005a). Detailed analyses of these independent effects would be of value in clinical decision making, and would help to improve understanding and identification of those patients most likely to benefit from rimonabant.

\section{Blood pressure and heart rate}

There is level 1 evidence based on the results of RIO-Europe, RIO-Lipids, and RIO-Diabetes, that rimonabant $20 \mathrm{mg} /$ day results in a mean reduction in systolic blood pressure of $2 \mathrm{mmHg}$ and diastolic blood pressure of $1 \mathrm{mmHg}$ (Curioni \& André 2006). The $5 \mathrm{mg} /$ day dose has no statistically significant effect, and the meta analysis indicated that because of substantial heterogeneity in the results, the pooled data on blood pressure were unreliable. Results from RIO-North America support these findings (Table 9).

The lack of a significant effect of rimonabant on blood pressure supports the use of rimonabant in obese patients with concomitant hypertension. This is potentially an important advantage given that obesity and hypertension often present together. Indeed, there is evidence that decreases in blood pressure are greater in patients with hypertension (baseline blood pressure $\geq 140 / 90 \mathrm{mmHg}$ ), with a mean reduction of $13.1 / 6.3$ with rimonabant $20 \mathrm{mg} /$ day compared with $7.2 / 2.4 \mathrm{mmHg}$ with placebo (Després et al. 2005a).

However, concern has been raised that the weight loss associated with rimonabant in RIO-Europe did not produce significant reductions in blood pressure (Astrup 2005). Weight loss of the reported magnitude with rimonabant $20 \mathrm{mg}$ might be expected to reduce blood pressure by $\sim 4 \mathrm{mmHg}$.

Heart rate appears to be unaffected by rimonabant (Després et al. 2005a; Van Gaal et al. 2005).

\section{Quality of life}

There is evidence from one RCT that rimonabant $20 \mathrm{mg} /$ day improves quality of life. The RIO-Diabetes study evaluated patients' quality of life using the Short-Form 36 questionnaire (SF-36) and the obesity-specific Impact of Weight on Quality of Life (IWQoL-Lite) instruments, and food behavior using a visual analog scale.

The study reported that more patients taking rimonabant $20 \mathrm{mg} /$ day reported satisfaction compared with placebo $(P=0.001)$, and showed a greater improvement in physical function, self-esteem, and total IWQoL-Lite score (Scheen et al. 2006). There was less desire for high-fat foods and sweets, greater ease of following diet, and reduced appetite in patients taking rimonabant. However, impairment in mental health score was greater in rimonabant recipients.

\section{Safety and tolerability}

Based on the pooled results from RIO-Europe, RIO-North America, and RIO-Diabetes, the Cochrane meta analysis revealed that there were significantly more general adverse events (1852 events in 2157 patients vs 1031/1260; $P=0.005$ ) and serious adverse events $(149 / 2503$ vs $69 / 1602 ; P=0.03)$ in patients receiving rimonabant $20 \mathrm{mg} /$ day compared with placebo (Curioni \& André 2006). Discontinuation of treatment due to tolerability was also significantly more common in patients receiving rimonabant $20 \mathrm{mg} /$ day $(13.8 \%$ vs $7 \% ; P<0.00001)$. The tolerability profile of the $5 \mathrm{mg} /$ day dose did not differ from placebo.

The most common adverse events reported by $\geq 5 \%$ of patients taking rimonabant $20 \mathrm{mg} /$ day included nausea, dizziness, diarrhea, anxiety, upper respiratory tract infection/influenza, insomnia, and arthralgia (Després et al. 2005a; Van Gaal et al. 
Table 9 | Effect of rimonabant on blood pressure $(\mathrm{mmHg})$ and heart rate $(\mathrm{bpm})$

\begin{tabular}{|c|c|c|c|c|c|c|}
\hline \multirow[t]{2}{*}{ Study } & \multirow[t]{2}{*}{ Reference } & \multirow{2}{*}{$\begin{array}{l}\text { Drugs and } \\
\text { dosage }(n)\end{array}$} & \multirow[t]{2}{*}{ Duration } & \multicolumn{3}{|c|}{ Outcome } \\
\hline & & & & DBP & SBP & HR \\
\hline \multirow[t]{3}{*}{ RIO-Lipids } & Deprés et al. 2005 & $\operatorname{Rim} 5$ (340) & 1 year & -0.5 & -0.4 & +0.2 \\
\hline & & $\operatorname{Rim} 20$ (344) & & $-2.9^{a}$ & -3.6 & +0.9 \\
\hline & & Pla (334) & & -0.8 & -0.7 & +0.7 \\
\hline \multirow[t]{3}{*}{ RIO-Europe } & Van Gaal et al. 2005 & $\operatorname{Rim} 5$ (603) & 1 year & -1.5 & -1.3 & NR \\
\hline & & Rim 20 (599) & & -1.8 & -2.0 & NR \\
\hline & & Pla (305) & & -0.4 & -0.4 & NR \\
\hline \multirow[t]{3}{*}{ RIO-North America } & Pi-Sunyer et al. 2006 & Rim 5 (1191) & 1 year & $+0.2^{\mathrm{b}}$ & $+0.2^{\mathrm{b}}$ & NR \\
\hline & & Rim 20 (1189) & & $-0.2^{\mathrm{b}}$ & $-0.3^{b}$ & NR \\
\hline & & Pla (590) & & $0^{\mathrm{a}}$ & $0^{\mathrm{a}}$ & NR \\
\hline \multirow[t]{3}{*}{ RIO-Diabetes } & Scheen et al. $2006^{c}$ & $\operatorname{Rim} 5$ (358) & 1 year & -0.4 & -0.4 & +0.9 \\
\hline & & $\operatorname{Rim} 20$ (339) & & -1.9 & -0.8 & +1.0 \\
\hline & & $\mathrm{Pla}(348)$ & & -0.7 & +1.6 & +0.8 \\
\hline
\end{tabular}

2005; Pi-Sunyer et al. 2006; Scheen et al. 2006). These events were generally considered to be mild to moderate in intensity and transient in nature, occurring mainly during the first months of the study. However, the high drop-out rate must also be considered. The available data suggest that rimonabant has a different tolerability profile to existing weight reduction therapies; in particular it does not appear to be associated with severe gastrointestinal adverse effects, clinically relevant elevations in blood pressure, or changes in liver, kidney, or blood physiology.

Since rimonabant is a centrally active novel pharmacologic agent, neuropsychologic effects must be considered a theoretical adverse effect warranting investigation. Indeed, the main category of adverse event leading to discontinuation of rimonabant $20 \mathrm{mg} /$ day was depressed mood. Patients with serious psychologic illness, neuropsychiatric disorders, or severe depression involving hospitalization, recurrent episodes, or suicide attempts, were excluded from RIO-Europe, RIO-North America, and RIO-Lipids (Després et al. 2005a; Van Gaal et al. 2005; Pi-Sunyer et al. 2006). To evaluate possible effects of rimonabant on mood and mental state, the Hospital Anxiety and Depression (HAD) rating scale, a short patient-reported questionnaire designed to screen for mood and psychiatric disorders in the primary care setting, was completed at baseline and at 3-month intervals in RIO-Europe, RIO-North America, and RIO-Diabetes. Patients scoring $\geq 11$ on HAD were referred to a psychiatrist for further assessment and treatment if necessary. After 1 year, there were no significant between-group differences in the mean (standard deviation) HAD scale subscores for depression (Després et al. 2005a; Van Gaal et al. 2005; Scheen et al. 2006).

Pharmacoepidemiologic evidence from the approximately 240000 patients who have received rimonabant worldwide indicates that one in ten may develop psychiatric side effects (MHRA 2007). In the UK, 318 cases of adverse events (921 events in total because of multiple events in the same patients) associated with rimonabant had been reported up to June 2007 in an estimated 41000 patients receiving the drug, including 364 neuropsychologic effects, of which 48 were depression, 16 were suicidal thoughts, and 1 was self harm (MHRA 2007).

Multiple sclerosis has been reported in one female patient who participated in RIO-Europe and had been taking rimonabant $5 \mathrm{mg} /$ day for approximately 6 months (van Oosten et al. 2004). This patient had no previous signs of neurologic illness. Her symptoms improved somewhat before discontinuation of rimonabant, but in the weeks after stopping the medication she made an almost complete recovery. The efficacy of cannabinoid agonists in slowing the degenerative pathology of multiple sclerosis has been documented, and provides a theoretical basis for cannabinoid blockade by rimonabant exacerbating the same pathologic processes. However, it is not possible to determine whether multiple sclerosis developed in this patient as a direct consequence of exposure to rimonabant.

\section{Resource utilization}

Rimonabant could have a significant impact on healthcare resource utilization, not only because of the large numbers of patients who may be eligible for treatment, but also because the available evidence suggests that rimonabant might reduce the need for polypharmacy in cardiovascular risk factor management. Pharmacoeconomic and resource utilization data relating to rimonabant have yet to be published. However, the encouraging efficacy and safety data published to date suggest that rimonabant could have a substantial impact on clinical practice in the management of patients with the metabolic syndrome and multiple cardiovascular risk factors. The additional metabolic benefits rimonabant seems to offer beyond weight loss, such as improved lipid and glycemic profiles, could potentially reduce the need for polypharmacy in risk factor modification, leading to reductions in overall obesity-related healthcare resource utilization. The cost of 1 year's treatment with rimonabant $20 \mathrm{mg} /$ day was reported as $£ 719$ in October 2006 in the UK (MTRAC 2006). 


\section{Patient group/population}

Rimonabant is approved in the European Union as an adjunct to diet and exercise for the treatment of obese (BMI $\geq 30 \mathrm{~kg} / \mathrm{m}^{2}$ ) or overweight patients (BMI $>27 \mathrm{~kg} / \mathrm{m}^{2}$ ) with associated risk factors including type 2 diabetes or dyslipidemia. It is not available in the USA.

Obesity is an umbrella term which tends to be applied to a highly heterogeneous and diverse cross-section of people of different ages, ethnic groups, socioeconomic status, and medical histories. RIO-Europe was designed to be representative of a realworld clinical setting (Van Gaal et al. 2005), but the authors of RIO-North America, which included patients with very similar characteristics, acknowledge their study had limited generalizability to clinical practice due to the overrepresentation of white women in the study population (Pi-Sunyer et al. 2006). Caution should therefore perhaps be exercised when extrapolating these data to the full spectrum of cases that present in clinical practice.

There is, nevertheless, evidence that rimonabant $20 \mathrm{mg} /$ day is effective in reducing bodyweight in obese or overweight patients with dyslipidemia and those with type 2 diabetes. The drug also appears to improve glucose control in diabetic patients previously untreated (Iranmanesh et al. 2006) or who are poorly controlled on metformin or sulfonylureas (Scheen et al. 2006). Weight loss may be lower in black patients due to higher clearance of the drug (Anon. 2007a).

\section{Dosage, administration, and formulations}

The dosage of rimonabant (Acomplia) in obese or overweight patients is $20 \mathrm{mg} /$ day orally in the morning before breakfast (Anon. 2007a). No dosage adjustment is required for elderly patients, or those with mild to moderate hepatic or renal impairment. Rimonabant should be used with caution in patients with moderate hepatic impairment and is contraindicated in severe hepatic or renal impairment. It is not recommended in patients under the age of 18 years or during pregnancy, and should only be used with caution in patients aged over 75 years and those with epilepsy. The European Medicines Agency (EMEA) recently recommended that rimonabant should not be used in patients with major depression or taking antidepressants (EMEA 2007). Caution is also recommended if given in combination with the potent CYP3A4 inhibitors ketoconazole, itraconazole, ritonavir, clarithromycin, telithromycin, and nefazodone, which may increase plasma levels of rimonabant. Conversely, CYP3A4 inducers like rifampicin, phenytoin, carbamazepine, and St John's Wort may decrease levels.

\section{Place in therapy}

The available evidence on rimonabant $20 \mathrm{mg} /$ day from four largescale RCTs indicates efficacy for up to 2 years on weight loss and across a range of cardiovascular and metabolic risk factors in obese and overweight patients, and in patients with diabetes and dyslipidemia (see the Evidence summary table on the opening page of this article). Approximately $50 \%$ of patients achieve weight loss of $\geq 5 \%$, with $\geq 10 \%$ in $16-32 \%$ of patients. These values are important because the Food and Drug Administration (FDA) threshold for antiobesity drugs is placebo-subtracted weight loss of $\geq 5 \%$, while that for the EMEA is $\geq 10 \%$, with both requiring a significant difference compared with placebo (Curioni \& André 2006). However, the FDA recently recommended that rimonabant should not be approved for use in obese and overweight patients with additional risk factors due to the risk of adverse psychiatric effects (Anon. 2007b); the EMEA concluded that the benefits of the drug outweigh the risks except in patients with major depression or taking antidepressants (EMEA 2007).

There are some concerns regarding the strength of the evidence for rimonabant's efficacy. First, the drop-out rate across all groups in the studies was high-approximately $40 \%$. Adverse events caused around $14 \%$ of rimonabant recipients to discontinue the drug (see above), while almost three times as many patients who gained weight stopped treatment (Scheen et al. 2006). Second, the studies have been criticized for inconsistently reporting methods of randomization, blinding, and statistical power calculations (Curioni \& André 2006). Third, the results may not be generalizable to clinical practice because of the highly selected patient populations (e.g. overrepresentation of white women) (Pi-Sunyer et al. 2006).

The trials were also all comparisons with placebo, rather than active drugs. The meta analysis of the RIO trials indicated a mean weight reduction of $4.6 \mathrm{~kg}$ with rimonabant $20 \mathrm{mg} /$ day after 1 year compared with placebo (Curioni \& André 2006). This is greater than the decreases of $2.7 \mathrm{~kg}$ with orlistat and $4.3 \mathrm{~kg}$ with sibutramine reported in another meta analysis (Padwal et al. 2003), although any differences would need to be substantiated in head-to-head comparisons. Furthermore, orlistat is associated with gastrointestinal adverse effects and lower HDL-C levels, and sibutramine with increased blood pressure. Another meta analysis in patients with diabetes reported mean weight loss of $2.6 \mathrm{~kg}$ with orlistat and $4.5 \mathrm{~kg}$ with sibutramine (Norris et al. 2004); in RIODiabetes, rimonabant $20 \mathrm{mg} /$ day reduced weight by $5.3 \mathrm{~kg}$ (Scheen et al. 2006). $\mathrm{HbA}_{1 \mathrm{c}}$ decreased by $0.6 \%$, compared with corresponding values of $0.4 \%$ with orlistat and $0.7 \%$ with sibutramine in the meta analysis (Norris et al. 2004).

There is preliminary evidence that rimonabant lowers $\mathrm{HbA}_{1 \mathrm{c}}$ by $0.8 \%$ in previously untreated diabetic patients, who also lost a mean of $6.7 \mathrm{~kg}$ in bodyweight (Iranmanesh et al. 2006). The evidence also points to a beneficial decrease in fasting glucose, fasting insulin, and insulin resistance with rimonabant in obese or overweight patients. Furthermore, other cardiovascular risk factors improved during rimonabant treatment, including increased HDL-C and adiponectin, and reduced TG, LDL:HDL and total:HDL-C ratios, and leptin and C-reactive protein levels. A direct effect of rimonabant has been suggested since changes in $\mathrm{HbA}_{1 \mathrm{c}}, \mathrm{HDL}-\mathrm{C}, \mathrm{TG}$, and adiponectin were independent of weight loss. The mechanism may be blockade of $\mathrm{CB} 1$ receptors by rimonabant leading to increased production of adiponectin, which would result in reduced abdominal fat deposition, and hence lower cardiovascular risk (Després et al. 2005a; Van Gaal et al. 
2005). Indeed the evidence shows that rimonabant significantly reduces waist circumference, and the prevalence of the metabolic syndrome.

The weight loss of $\geq 5 \%$ achieved with rimonabant $20 \mathrm{mg} /$ day together with the beneficial effects on lipid and glucose metabolism indicate that the drug should reduce cardiovascular risk in obese and overweight patients, including those with diabetes. Diet and exercise remain the first-line options for managing weight loss but in those patients who require an additional pharmacologic intervention, the evidence suggests that rimonabant appears effective. The long-term effectiveness of any intervention aimed at reducing weight is obviously dependent on patient compliance, which is often poor. Patient support, such as the program provided by the manufacturer of rimonabant, may help to improve this aspect of treatment.

Although implied by what is currently available, there is at present no hard evidence that the beneficial effects of rimonabant on risk factors translate into cardiovascular endpoints. The ongoing CRESCENDO (Comprehensive Rimonabant Evaluation Study of Cardiovascular Endpoints and Outcomes) trial will be particularly important in this regard. The primary objective of this double-blind RCT, which is expected to enroll 17000 patients aged $\geq 55$ years with abdominal obesity and other cardiovascular risk factors, is to show whether rimonabant $20 \mathrm{mg} /$ day reduces the risk of myocardial infarction, stroke, or death from a myocardial infarction or stroke. The results are awaited with interest.

\section{Acknowledgments}

The authors declare that they have no conflict of interest.

\section{References}

Allison DB, Fontaine KR, Manson JE, Stevens J, Vanltallie TB. Annual deaths attributable to obesity in the United States. JAMA. 1999;282:1530-1538.

Anon. Best of the ACC Scientific Session 2004. Rev Cardiovasc Med. 2004a;5:104-129.

Anon. News from the European Society of Cardiology congress 2004. Br J Cardiol. 2004b;11:354-355.

Anon. Reports from the American College of Cardiology 53rd Annual Scientific Session. Br J Cardiol. 2004c;11:99-104.

Anon. Special report: clinical news updates from the 2004 AHA Scientific Sessions. Formulary. 2005;40:22-28.

Anon. Acomplia $20 \mathrm{mg}$ film-coated tablets. Summary of product characteristics. Surrey: Sanofi-Aventis; June 28, 2006. Available at: http://emc.medicines.org.uk/emc/assets/c/html/displaydoc.asp?documentid= 18283 (accessed January 12, 2007a).

Anon. FDA advisory committee did not recommend approval of rimonabant $\left(\right.$ Zimulti $\left.^{\circledR}\right)$ for use in obese and overweight patients with associated risk factors. Paris: Sanofi-Aventis press release; June 13, 2007. Available at: http://www.sanofi-aventis.us/live/us/medias/20F41CB7-37FE-44F6-BF8146EBF7BDB04A.pdf (accessed August 7, 2007b).

Astrup A. Effect of rimonabant on weight reduction and cardiovascular risk. Lancet. 2005;366:368; author reply 369-370.

Bolen JC, Rhodes L, Powell-Griner EE, Bland SD, Holtzman D. State-specific prevalence of selected health behaviors, by race and ethnicity-behavioral risk factor surveillance system, 1997. MMWR CDC Surveill Summ. 2000;49:1-60.
Cerulli J, Malone M. Outcomes of pharmacological and surgical treatment for obesity. Pharmacoeconomics. 1998;14:269-283.

CDC (Centers for Disease Control and Prevention). Overweight and obesity: economic consequences. Available at: http://www.cdc.gov/nccdphp/dnpa/obesity/economic_consequences.htm (accessed July 2005).

CDC (Centers for Disease Control and Prevention). National diabetes fact sheet: general information and national estimates on diabetes in the United States, 2003. Atlanta, GA: US Department of Health and Human Services, Centers for Disease Control and Prevention, 2004. Available at: http://www.cdc.gov/diabetes/pubs/factsheet.htm (accessed July 2005).

Cleland JG, Ghosh J, Freemantle N, et al. Clinical trials update and cumulative meta-analyses from the American College of Cardiology: WATCH, SCD-HeFT, DINAMIT, CASINO, INSPIRE, STRATUS-US, RIO-Lipids and cardiac resynchronisation therapy in heart failure. Eur $\mathrm{J}$ Heart Fail. 2004;6:501-508.

Considine RV. Human leptin: an adipocyte hormone with weight-regulatory and endocrine functions. Semin Vasc Med. 2005;5:15-24.

Cota D, Marsicano G, Tschöp M, et al. The endogenous cannabinoid system affects energy balance via central orexigenic drive and peripheral lipogenesis. J Clin Invest. 2003;112:423-431.

Cottam DR, Mattar SG, Barinas-Mitchell E, et al. The chronic inflammatory hypothesis for the morbidity associated with morbid obesity: implications and effects of weight loss. Obes Surg. 2004;14:589-600.

Curioni C, André C. Rimonabant for overweight or obesity. Cochrane Database Syst Rev. 2006;(4):CD006162.

Davidson MH, Hauptman J, DiGirolamo M, et al. Weight control and risk factor reduction in obese subjects treated for 2 years with orlistat: a randomized controlled trial. JAMA. 1999;281:235-242 (erratum JAMA. 1999;281:1174).

De Souza CT, Araujo EP, Bordin S, et al. Consumption of a fat-rich diet activates a pro-inflammatory response and induces insulin resistance in the hypothalamus. Endocrinology. 2005;146:4192-4199.

Després J-P, Golay A, Sjöström L; Rimonabant in Obesity-Lipids Study Group. Effects of rimonabant on metabolic risk factors in overweight patients with dyslipidemia. N Engl J Med. 2005a;353:2121-2134.

Després J-P, Golay A, Sjöström L; RIO-Lipids Study Group. One-year treatment with rimonabant increases plasma adiponectin levels beyond weight loss: the RIO-lipids trial. Presented at: 65th American Diabetes Association annual scientific session; June 10-14, 2005b; San Diego, CA. Abstract 7-LB.

Di Marzo V, Goparaju SK, Wang L, et al. Leptin-regulated endocannabinoids are involved in maintaining food intake. Nature. 2001;410:822-825.

EMEA (European Medicines Agency). European Medicines Agency recommends Acomplia must not be used in patients on antidepressants or with major depression. London: EMEA press release; July 19, 2007. Available at: http://www.emea.europa.eu/humandocs/PDFs/EPAR/acomplia/32982607en.pdf (accessed August 7, 2007).

Esposito K, Giugliano D. Effect of rimonabant on weight reduction and cardiovascular risk. Lancet. 2005;366:367-368; author reply 369-370.

Faxon D, Fonarow G, Jacobs A, et al. Best of the AHA Scientific Sessions 2004. Highlights from the American Heart Association Scientific Sessions November 7-10, 2004, New Orleans, LA. Rev Cardiovasc Med. 2005;6:33-46.

Fernandez JR, Allison DB. Rimonabant Sanofi-Synthélabo. Curr Opin Investig Drugs. 2004;5:430-435.

Flegal KM, Carroll MD, Ogden CL, Johnson CL. Prevalence and trends in obesity among US adults, 1999-2000. JAMA. 2002;288:1723-1727.

Flegal KM, Graubard BI, Williamson DF, Gail MH. Excess deaths associated with underweight, overweight, and obesity. JAMA. 2005;293:1861-1867.

Fontaine KR, Redden DT, Wang C, Westfall AO, Allison DB. Years of life lost due to obesity. JAMA. 2003;289:187-193.

Ford ES, Giles WH, Dietz WH. Prevalence of the metabolic syndrome among US adults: findings from the third National Health and Nutrition Examination Survey. JAMA. 2002;287:356-359. 
Fry J, Finley W. The prevalence and costs of obesity in the EU. Proc Nutr Soc. 2005;64:359-362.

Gerich JE. Contributions of insulin-resistance and insulin-secretory defects to the pathogenesis of type 2 diabetes mellitus. Mayo Clin Proc. 2003;78:447-456.

Gomaraschi M. European Atherosclerosis Society-75th congress. IDrugs. 2005;8:555-559.

Gordon DJ, Probstfield JL, Garrison RJ, et al. High-density lipoprotein cholesterol and cardiovascular disease. Four prospective American studies. Circulation. 1989;79:8-15.

Hanefeld M, Sachse G. The effects of orlistat on body weight and glycaemic control in overweight patients with type 2 diabetes: a randomized, placebocontrolled trial. Diabetes Obes Metab. 2002;4:415-423.

Harp JB. Orlistat for the long-term treatment of obesity. Drugs Today (Barc). 1999;35:139-145.

Hauner $\mathrm{H}$. Managing type 2 diabetes mellitus in patients with obesity. Treat Endocrinol. 2004;3:223-232.

Havel PJ. Role of adipose tissue in body-weight regulation: mechanisms regulating leptin production and energy balance. Proc Nutr Soc. 2000;59:359-371.

Hedley AA, Ogden CL, Johnson CL, Carroll MD, Curtin LR, Flegal KM. Prevalence of overweight and obesity among US children, adolescents, and adults, 1999-2002. JAMA. 2004;291:2847-2850.

Hogan P, Dall T, Nikolov P; American Diabetes Association. Economic costs of diabetes in the US in 2002. Diabetes Care. 2003;26:917-932.

IOTF (International Obesity Taskforce). Prevalence of adult obesity. London:

IOTF; June 2007. Available at:

http://www.iotf.org/database/GlobalAdultTableJune07.htm (accessed

August 9, 2007).

Iranmanesh A, Rosenstock J, Hollander P; SERENADE Study Group.

SERENADE: rimonabant monotherapy for treatment of multiple cardiometabolic risk factors in treatment-naïve patients with type 2 diabetes. Presented at: 19th World Diabetes Congress; December 3-7, 2006; Cape Town, South Africa. Abstract 637b.

James PT. Obesity: the worldwide epidemic. Clin Dermatol. 2004;22:276-280. James P, Rigby N. The challenge to movers and shakers: broad strategies to prevent obesity and diabetes. Diabetes Voice. 2004;49:8-10.

Jbilo O, Ravinet-Trillou C, Arnone M, et al. The CB1 receptor antagonist rimonabant reverses the diet-induced obesity phenotype through the regulation of lipolysis and energy balance. FASEB J. 2005;19:1567-1569.

Jéquier E. Leptin signaling, adiposity, and energy balance. Ann N Y Acad Sci. 2002;967:379-388.

Jotangia D, Moody A, Stamatakis E, Wardle $\mathrm{H}$. Obesity among children under 11. London: Department of Health; April 29, 2005. Available at: http://www.dh.gov.uk/PublicationsAndStatistics/Publications/PublicationsStatist ics/PublicationsStatisticsArticle/fs/en?CONTENT_ID=4109245\&chk=WB/AR1 (accessed July 2005).

Kaplan LM. Pharmacological therapies for obesity. Gastroenterol Clin North Am. 2005;34:91-104.

Khaodhiar L, McCowen KC, Blackburn GL. Obesity and its comorbid conditions. Clin Cornerstone. 1999;2:17-31.

Kirkham TC, Williams CM. Synergistic effects of opioid and cannabinoid antagonists on food intake. Psychopharmacol (Berl). 2001;153:267-270.

Kirkham TC, Williams CM. Endocannabinoid receptor antagonists: potential for obesity treatment. Treat Endocrinol. 2004;3:345-360.

Kopelman P. Prescribing for obesity. Comment on the Royal College of Physicians' Working Party report on clinical management of overweight and obese patients with particular reference to drugs. $J$ R Coll Physicians Lond. 1999;33:31-32.

Kopp HP, Krzyzanowska K, Mohlig M, Spranger J, Pfeiffer AF, Schernthaner G. Effects of marked weight loss on plasma levels of adiponectin, markers of chronic subclinical inflammation and insulin resistance in morbidly obese women. Int J Obes (Lond). 2005;29:766-771.
Lakka HM, Laaksonen DE, Lakka TA, et al. The metabolic syndrome and total and cardiovascular disease mortality in middle-aged men. JAMA.

2002;288:2709-2716.

Larsson U, Karlsson J, Sullivan M. Impact of overweight and obesity on healthrelated quality of life-a Swedish population study. Int J Obes Relat Metab Disord. 2002;26:417-424.

Luque CA, Rey JA. The discovery and status of sibutramine as an anti-obesity drug. Eur J Pharmacol. 2002;440:119-128.

Mayor S. Conference report: American College of Cardiology annual scientific session (7-10 March, New Orleans). Int J Clin Pract. 2004;58:417-419.

McMahon FG, Fujioka K, Singh BN, et al. Efficacy and safety of sibutramine in obese white and African American patients with hypertension: a 1-year, doubleblind, placebo-controlled, multicenter trial. Arch Intern Med.

2000;160:2185-2191.

Meigs JB. Epidemiology of the metabolic syndrome, 2002. Am J Manag Care. 2002;8(11 Suppl.):S283-S292.

Meigs JB, D'Agostino RB Sr, Wilson PW, Cupples LA, Nathan DM, Singer DE. Risk variable clustering in the insulin resistance syndrome. The Framingham Offspring Study. Diabetes. 1997;46:1594-1600.

MHRA (Medicines and Healthcare Products Regulatory Agency). New advice concerning the use of Acomplia (rimonabant) for weight loss in patients taking antidepressants or those with major depression. London: MHRA; July 19, 2007. Available at:

http://www.mhra.gov.uk/home/idcplg?ldcService=SS_GET_PAGE\&useSecondar $\mathrm{y}=$ true\&ssDocName=CON2031809\&ssTargetNodeld=221 (accessed August 7, 2007).

MTRAC (Midlands Therapeutics Review and Advisory Committee). Verdict and summary: rimonabant $\left(\right.$ Acomplia $\left.^{\circledR}\right)$ for the treatment of obesity. October 2006. Available at

http://www.keele.ac.uk/schools/pharm/MTRAC/Productlnfo/verdicts/R/Rimona bant.pdf (accessed January 12, 2007).

Muls E, Kolanowski J, Scheen A, Van Gaal L; ObelHyx Study Group. The effects of orlistat on weight and on serum lipids in obese patients with hypercholesterolemia: a randomized, double-blind, placebo-controlled, multicentre study. Int J Obes Relat Metab Disord. 2001;25:1713-1721.

NCEP (National Cholesterol Education Program). Third report of the expert panel on detection, evaluation, and treatment of high blood cholesterol in adults (Adult Treatment Panel III). September 2002. Available at:

http://www.nhlbi.nih.gov/guidelines/cholesterol/atp3full.pdf (accessed July 2005).

Nesto R. C-reactive protein, its role in inflammation, type 2 diabetes and cardiovascular disease, and the effects of insulin-sensitizing treatment with thiazolidinediones. Diabet Med. 2004;21:810-817.

NHSC (National Horizon Scanning Centre). Rimonabant for smoking cessation, weight loss and cardiovascular risk factors of overweight/obesity. Birmingham: NHSC; 2004: Available at:

http://www.crd.york.ac.uk/crdweb/ShowRecord.asp?View=Full\&ID=3200400088 0 (accessed July 2005).

NICE (National Institute for Health and Clinical Excellence). A systematic review of the clinical effectiveness and cost-effectiveness of sibutramine in the management of obesity. London: NICE; October 2001. Available at: http://www.nice.org.uk/pdf/sibutraminehtareport.pdf (accessed July 2005).

NICE (National Institute for Health and Clinical Excellence). Obesity: the prevention, identification, assessement and management of overweight and obesity in adults and children. London: NICE; December 2006. Available at: http://guidance.nice.org.uk/CG43 (accessed August 9, 2007).

$\mathrm{NIH}$ (National Institutes of Health). Clinical guidelines on the identification, evaluation, and treatment of overweight and obesity in adults. Bethesda, MD: Department of Health and Human Services, NIH, National Heart, Lung, and Blood Institute; September 1998. Available at: http://www.nhlbi.nih.gov/guidelines/obesity/ob_gdlns.pdf (accessed July 2005).

Norris SL, Zhang X, Avenell A, et al. Efficacy of pharmacotherapy for weight loss in adults with type 2 diabetes mellitus: a meta-analysis. Arch Intern Med. 2004;164:1395-1404. 
Olshansky SJ, Passaro DJ, Hershow RC, et al. A potential decline in life expectancy in the United States in the 21st century. N Engl J Med. 2005;352:1138-1145.

Padwal R, Li SK, Lau DC. Long-term pharmacotherapy for obesity and overweight. Cochrane Database Syst Rev. 2003;(4):CD004094.

Pagotto U, Vicennati V, Pasquali R. The endocannabinoid system and the treatment of obesity. Ann Med. 2005;37:270-275.

Pender JR, Pories WJ. Epidemiology of obesity in the United States. Gastroenterol Clin North Am. 2005;34:1-7.

Pi-Sunyer FX, Aronne LJ, Heshmati HM; RIO-North America Study Group. Effect of rimonabant, a cannabinoid-1 receptor blocker, on weight and cardiometabolic risk factors in overweight or obese patients: RIO-North America: a randomized controlled trial. JAMA. 2006;295:761-775.

Poirier B, Bidouard JP, Cadrouvele C, et al. The anti-obesity effect of rimonabant is associated with an improved serum lipid profile. Diabetes Obes Metab. 2005;7:65-72.

Rahmouni K, Morgan DA, Morgan GM, Mark AL, Haynes WG. Role of selective leptin resistance in diet-induced obesity hypertension. Diabetes. 2005;54:2012-2018.

Reaven GM. The insulin resistance syndrome: definition and dietary approaches to treatment. Annu Rev Nutr. 2005;25:391-406.

Reaven G, Abbasi F, McLaughlin T. Obesity, insulin resistance, and cardiovascular disease. Recent Prog Horm Res. 2004;59:207-223.

Rosenstock J. The potential of rimonabant in prediabetes: pooled 1-year results from the RIO-Lipids, RIO-Europe and RIO-North America studies. Presented at: 65th American Diabetes Association annual scientific session; June 10-14, 2005b; San Diego, CA. Abstract 13-LB.

Salopuro T, Pulkkinen L, Lindstrom J, et al. Genetic variation in leptin receptor gene is associated with type 2 diabetes and body weight: the Finnish diabetes prevention study. Int J Obes (Lond). 2005;29:1245-1251.

Saw SM, Rajan U. The epidemiology of obesity: a review. Ann Acad Med Singapore. 1997;26:489-493.

Scheen AJ, Finer N, Hollander P, for the RIO-Diabetes Study Group. Efficacy and tolerability of rimonabant in overweight or obese patients with type 2 diabetes: a randomized controlled study. Lancet. 2006;368:1660-1672. (erratum Lancet. 2006;368:1650.)

Shah S, Patel M, Goyal A, et al. Highlights from the American Heart Association Annual Scientific Sessions: November 7-10, 2004. Am Heart J. 2005;149:240-253.

Sheetz MJ, King GL. Molecular understanding of hyperglycemia's adverse effects for diabetic complications. JAMA. 2002;288:2579-2588.

Snow V, Barry P, Fitterman N, Qaseem A, Weiss K; Clinical Efficacy Assessment Subcommittee of the American College of Physicians. Pharmacologic and surgical management of obesity in primary care: a clinical practice guideline from the American College of Physicians. Ann Intern Med. 2005;142:525-531.

Susman E. American Heart Association-Scientific Sessions 2004. 7-10 November 2004, New Orleans, LA, USA. IDrugs. 2004;7:1081-1084.

Tankova T, Dakovska G, Lazarova M, Dakovska L, Kirilov G, Koev D. Sibutramine in the treatment of obesity in type 2 diabetic patients and in nondiabetic subjects. Acta Diabetol. 2004;41:146-153.
Torgerson JS, Hauptman J, Boldrin MN, Sjöström L. Xenical in the prevention of diabetes in obese subjects (XENDOS) study: a randomized study of orlistat as an adjunct to lifestyle changes for the prevention of type 2 diabetes in obese patients. Diabetes Care. 2004;27:155-161. (erratum Diabetes Care. 2004;27:856.)

Trayhurn P. Endocrine and signalling role of adipose tissue: new perspectives on fat. Acta Physiol Scand. 2005;184:285-293.

Valsamakis G, Chetty RK, Kumar S. The management of obesity in type 2 diabetes mellitus. Curr Med Res Opin. 2002;18(Suppl. 1):S75-S81.

Van Gaal LF, Rissanen AM, Scheen AJ, Ziegler O, Rössner S; RIO-Europe Study Group. Effects of the cannabinoid-1 receptor blocker rimonabant on weight reduction and cardiovascular risk factors in overweight patients: 1-year experience from the RIO-Europe study. Lancet. 2005;365:1389-1397.

van Oosten BW, Killestein J, Mathus-Vliegen EM, Polman CH. Multiple sclerosis following treatment with a cannabinoid receptor-1 antagonist. Mult Scler. 2004;10:330-331.

Weinstock R. Treating type 2 diabetes mellitus: a growing epidemic. Mayo Clin Proc. 2003;78:411-413.

Weiss D. How to help your patients lose weight: current therapy for obesity. Cleve Clin J Med. 2000;67:739, 743-746, 749-754.

Wellman NS, Friedberg B. Causes and consequences of adult obesity: health, social and economic impacts in the United States. Asia Pac J Clin Nutr. 2002;11(Suppl. 8):S705-S709.

WHO (World Health Organization). Obesity and overweight. Global strategy on diet, physical activity and health. Geneva: WHO; 2003. Available at: http://www.who.int/hpr/NPH/docs/gs_obesity.pdf (accessed July 2005).

Williams CM, Kirkham TC. Reversal of delata 9-THC hyperphagia by SR141716 and naloxone but not dexfenfluramine. Pharmacol Biochem Behav. 2002;71:333-340.

Winkler JT. The fundamental flaw in obesity research. Obes Rev. 2005;6:199-202.

Wolf AM, Colditz GA. Current estimates of the economic cost of obesity in the United States. Obes Res. 1998;6:97-106.

Yamagishi S, Imaizumi T. Diabetic vascular complications: pathophysiology, biochemical basis and potential therapeutic strategy. Curr Pharm Des. 2005;11:2279-2299.

Zhu S, Wang Z, Heshka S, Heo M, Faith MS, Heymsfield SB. Waist circumference and obesity-associated risk factors among whites in the third National Health and Nutrition Examination Survey: clinical action thresholds. Am J Clin Nutr. 2002;76:743-749.

Ziegler D. Type 2 diabetes as an inflammatory cardiovascular disorder. $\underline{\text { Curr Mol }}$ Med. 2005;5:309-322.

Zimmet P, Boyko EJ, Collier GR, de Courten M. Etiology of the metabolic syndrome: potential role of insulin resistance, leptin resistance, and other players. Ann N Y Acad Sci. 1999;892:25-44.

Correspondence: Paul Chrisp, Core Medical Publishing, Mere House, Brook Street, Knutsford, Cheshire WA16 8GP or at editor@coreevidence.com 